WARSZTATY Z GEOGRAFII TURYZMU

ISBN 978-83-7525-925-4 $\quad$ s. 9-19

http://dx.doi.org/10.18778/7525-925-4.02

Stanisław LISZEWSKI

Uniwersytet Łódzki

\title{
TREŚCI, FORMY, PRZESTRZENIE I KLASYFIKACJE TURYSTYKI (ARTYKUŁ DYSKUSYJNY)
}

\section{Wstęp}

Przegląd coraz bogatszej literatury dotyczącej definiowania zjawiska ${ }^{1}$ nazywanego turystyką wykazuje ogromną różnorodność pojęć, których liczba wzrasta proporcjonalnie do rozwoju aktywności turystycznej współczesnego człowieka. Dotyczy to zarówno treści, czyli celów podróży uznawanych za turystyczne, form (rodzajów), w jakich realizuje się to zjawisko, jak również przestrzeni, czyli obszarów, na których dokonuje się ta aktywność turystyczna człowieka.

Rozwój liczby nazw, jakimi określa się dziś tzw. nowe formy turystyki, jest efektem dwóch przeciwstawnych tendencji - uszczegółowiania i uogólniania.

Tendencja uszczegółowiania nazywanych wcześniej w sposób ogólny rodzajów turystyki prowadzi do powstania wielu nowych określeń. Przykładem może być nazwa turystyka morska, którą ze względu na rodzaj obiektu pływającego dzieli się na: rejsy wycieczkowe na statkach żeglugi przybrzeż-

\footnotetext{
${ }^{1}$ Zjawisko - to co zaszło, co się wydarzyło, przejawiło, ukazało, fakt, zdarzenie (SZYMCZAK, red. 1978).
} 
nej, rejsy na promach morskich, rejsy na statkach handlowo-towarowych, rejsy na jachtach morskich, morską turystykę wycieczkową (KUREK, red. 2007). Przyjmując za podstawę np. sposób spędzania czasu podczas pobytu na morzu możemy dalej uszczegóławiać ten rodzaj turystyki, dzieląc ją na: morską turystykę wypoczynkową morską turystykę rozrywkową, morską turystykę kwalifikowaną (surfing, wędkowanie, nurkowanie) itd.

Z drugiej strony poszukujemy określeń ogólnych, które wprawdzie same w sobie są mało precyzyjne, ale uogólniają określoną sferę działalności turystycznej. Przykładem może tu być określenie "turystyka alternatywna", czasem nazywana „miękką" czy łagodną w stosunku do zachowań „twardych" lub agresywnych dużych grup turystów wobec środowiska przyrodniczego czy społecznego. Bardziej rozpoznawalnym przykładem jest "turystyka kwalifikowana", czyli taka, do uprawiania której potrzebny jest sprzęt specjalistyczny i umiejętności posługiwania się nim (turystyka żeglarska, narciarska, kajakowa, konna, rowerowa i inne). Szczególnym rodzajem kompleksowo rozumianej formy turystyki jest krajoznawstwo, które coraz bardziej jest pomijane we współczesnej literaturze, a które najpełniej oddaje jedną z najważniejszych funkcji turystycznych - poznanie.

Ten ogromny bałagan pojęciowy potęgowany jest dodatkowo różnym podejściem do badań nad zjawiskiem turystyki przez przedstawicieli różnorodnych dziedzin i dyscyplin naukowych. Najogólniej rzecz ujmując, wielodyscyplinarność badań nad turystyką nie zaowocowała wypracowaniem wspólnych definicji pojęć ani klasyfikacji tego bardzo złożonego i wieloaspektowego zjawiska.

\section{Definicje i pojęcia w turystyce}

Współczesna turystyka postrzegana jest głównie jako zjawisko społeczno-gospodarcze dokonujące się w przestrzeni geograficznej (LISZEWSKI 2005). Określenie to jest identyfikowane zmysłowo i jest faktem empirycznym. Tak szerokie rozumienie turystyki nie budzi kontrowersji wśród badaczy, znacznie trudniej jest natomiast dojść do porozumienia przy tworzeniu definicji operacyjnych tego zjawiska.

Aby uzmysłowić sobie, jakie zmiany zaszły w pojmowaniu, a zwłaszcza definiowaniu turystyki w drugiej połowie XX w., przyjrzyjmy się, jak okreś- 
lano to zjawisko $\mathrm{w}$ połowie i w końcu tego wieku. Przypomnijmy definicję z 1951 r. autorstwa W. Hunzikera i K. Krapfta, którzy uważali, że: „turystyka to całokształt stosunków i zjawisk związanych z podróżą i pobytem w jakiejś miejscowości osób przyjezdnych, jeśli ich pobyt nie wynika z motywów osiedlania się i nie wiąże się z jakąkolwiek działalnością zarobkową" (za: KUREK, red. 2007, s. 12). Interpretacja tej definicji wyraźnie wskazuje na to, jak szeroki zakres już wówczas przypisywano pojęciu "turystyka”. Praktycznie turystami nazywano wszystkie osoby przybyłe z zewnątrz z wykluczeniem tylko dwóch motywów: osiedlania się (nie wiemy czy na stałe, czy na konkretny okres) oraz działalności zarobkowej, która też nie została precyzyjnie określona. $\mathrm{W}$ tej definicji nie podano ani długości pobytu, ani też konkretnych celów przyjazdu. Usprawiedliwieniem małej precyzyjności tej definicji może być czas jej powstania, czyli okres po zakończeniu II wojny światowej, kiedy wyjazdy turystyczne zwłaszcza w Europie były bardzo ograniczone, przez co łatwo czytelne i powszechnie rozpoznawalne.

Pewnym zaskoczeniem może jednak być definicja, która powstała blisko pół wieku później i została zaprezentowana przez Brytyjskie Towarzystwo Turystyczne (GAWORECKI 2010, s. 18). Według tej definicji: „Turystyka obejmuje wszelką czynność związaną z czasowym krótkotrwałym przemieszczaniem się osób do miejsc docelowych poza miejscami, gdzie normalnie mieszkają i pracują oraz pobytem w tych miejscach". Określenie to praktycznie otwiera możliwości zaliczenia do grupy turystów niemal każdego podróżującego (wyjeżdżającego z miejsca swojego zamieszkania), nie wymienia bowiem nawet celu podróży nazywanej turystyczną.

Tak szeroko definiowane zjawisko turystyki jest powodem zaliczania do grona turystów osób podróżujących, np. w celach zawodowych („turystyka biznesowa”), uczestników kongresów („turystyka kongresowa”), w celach handlowych i wiele innych. Dzieje się tak chyba dlatego, że w niektórych grupach społecznych nie uznaje się za pracę zawodową działalności biznesowej, naukowej czy politycznej(?). Jedynym wytłumaczeniem tak nieprecyzyjnego określenia turystyki może być chęć ułatwienia w zbieraniu materiałów statystycznych dotyczących ruchu turystycznego. Bowiem wszyscy nocujący $\mathrm{w}$ hotelach i innych obiektach noclegowych $\mathrm{w}$ świetle tej definicji są turystami.

Należy jednak pamiętać, że obok wielu definicji turystyki, które można znaleźć w każdym podręczniku istnieją również zalecenia i sugestie Światowej Organizacji Turystyki (UN WTO), która proponuje, aby w badaniach 
nad zjawiskiem turystyki uwzględnić m.in. cele odbywanych podróży oraz długość pobytu w miejscu docelowym. Wśród celów uznanych za charakterystyczne dla turystyki UN WTO wymienia m.in.: wypoczynek, rekreację, wakacje, odwiedziny u krewnych i znajomych, cele zdrowotne i pielgrzymkowe, ale również sprawy zawodowe i interesy(?)

Nie wdając się $\mathrm{w}$ dalszą polemikę pragnę stwierdzić, że przed badaczami zajmującymi się zjawiskiem, które nazywane jest turystyką wciąż stoi wielkie zadanie: poprawnego, to znaczy kompleksowego, ale zarazem precyzyjnego zdefiniowania tego pojęcia przy uwzględnieniu czterech głównych składowych: człowieka jako podmiotu turystyki, czasu wolnego jako warun$\mathrm{ku}$ uczestnictwa w tym zjawisku, ruchu turystycznego jako wyrazu przemieszczania się $\mathrm{w}$ przestrzeni geograficznej oraz skutków i konsekwencji przyrodniczych, społecznych i gospodarczych związanych z podróżą pobytem i obsługą turystów w konkretnej przestrzeni. Tak kompleksowe, lecz precyzyjne zdefiniowanie turystyki może dopiero stać się podstawą zintegrowanych badań nad tym zjawiskiem (LISZEWSKI 2005). Bez precyzyjnego określenia przedmiotu badań trudno będzie podejmować studia teoretyczne, ale również badania empiryczne turystyki.

Przed przystąpieniem do dalszych rozważań terminologicznych trzeba wpierw odpowiedzieć na pytanie, jaki jest cel podróży turystycznych? Jest to zarazem pytanie o treść tego zjawiska, czyli o to, w jakich okolicznościach człowiek wybierający się w podróż staje się turystą?

Historycznie rzecz ujmując wydaje się, że były to i nadal są cztery główne motywy podejmowania podróży, które dzisiaj nazywamy turystycznymi: chęć poznawania nowych obszarów, ich mieszkańców, ich kultury (motyw poznawczy), potrzeba bliższego nawiązania kontaktów - łączności z Bogiem (motyw duchowy), ratowanie zdrowia (motyw zdrowotny - witalny) oraz wypoczynek (rekreacja).

Wraz z rozwojem cywilizacyjnym świata pojawiły się kolejne motywy odbywania podróży, a wśród nich m.in. doznanie silnych przeżyć, rozrywkowo-zabawowy, towarzyski, kulturalny i wiele innych. Poszerzyły się także pierwotne motywy podróżowania.

Cele, czyli treści współczesnej turystyki są najczęściej złożone, bowiem człowiek podejmujący podróż pragnie skorzystać z szerokiej oferty turystycznej, wśród której dominuje rozrywka i wypoczynek, który może przyjmować różne formy i mieć różny zakres (fizyczny, duchowy, psychiczny), nigdzie jednak w literaturze przedmiotu nie spotkałem, aby wyjazd tury- 
styczny miał jako cel wykonywanie pracy czy zarobkowanie. Próba poszerzenia definicji turystyki o taką działalność (biznes, kongresy, targi i inne) moim zdaniem jest nieporozumieniem, które zaciera podstawowy cel wyjazdów turystycznych realizowanych przecież wyłącznie w tzw. czasie wolnym człowieka, tj. wolnym od pracy, nauki i innych obowiązkowych czynności czy zadań.

Współczesne życie jest jednak bardziej złożone niż mogą to przewidzieć twórcy różnych definicji. Potwierdza to przykład coraz częstszych ostatnio wyjazdów wakacyjnych (czyli w czasie wolnym) młodych ludzi, głównie studentów, którzy czasami dzielą swój wyjazd na dwie (niekoniecznie równe) części. Pierwsza to praca zarobkowa (gromadzenie środków finansowych), a druga - okres podróży turystycznych, zwiedzania, wypoczynku, rozrywki (SZYMAŃCZYK 2010). Jest to przykład łączenia w czasie wolnym (wakacje) dwóch różnych celów: pracy zarobkowej i różnych form turystyki. Funkcje te są jednak realizowane nie równolegle, ale w różnym czasie.

W odniesieniu do wyjazdów zarobkowo-turystycznych zjawisko to wymaga głębszego poznania, precyzyjnego określenia i wprowadzenia $\mathrm{w}$ formie wyraźnego zapisu do definicji turystyki.

Warto w tym miejscu odnieść się również do tzw. turystyki kongresowej, która powszechnie zaliczana jest obecnie do głównych form turystyki. Badania empiryczne przeprowadzone przez J. KOTLICKĄ (2010) podczas 31. Międzynarodowej Konferencji Promieni Kosmicznych, która odbyła się w Łodzi w 2009 r. przy udziale 758 uczestników, w tym 708 gości zagranicznych, rzuciły nowe światło na to zjawisko. Zainteresowanie aktywnością turystyczną wśród uczestników tej dużej międzynarodowej konferencji było bardzo niewielkie. Tylko 6,4\% uczestników zdecydowało się wziąć udział w proponowanych przez organizatorów wycieczkach do Krakowa $(4,6 \%)$ i Torunia (1,8\%), a aż 44\% nie uczestniczyło w żadnej formie turystyki podczas kongresu (nawet w wycieczce po Łodzi, w której absolutna większość uczestników była po raz pierwszy).

Przytoczone przykłady dotyczące łączenia pracy z turystyką $\mathrm{w}$ czasie wolnym oraz uczestnictwa $w$ dużych międzynarodowych kongresach wyraźnie wskazują na potrzebę podjęcia dyskusji nad ustaleniem kompleksowej, ale precyzyjnej definicji zjawiska turystyki, w przeciwnym razie coraz mniej realne stanie się określenie zarówno przedmiotu badań turystycznych, jak i podmiotu tych badań, czyli turystów, nie mówiąc już o określeniu przynajmniej przybliżonej wielkości ruchu turystycznego. 
Przechodząc do dalszych rozważań terminologicznych zajmiemy się interpretacją pojęcia "forma turystyki". Określenie forma w Stowniku języka polskiego (SZYMCZAK 1978) ma wielorakie znaczenie. Słowo to wywodzi się z łaciny i w prostym tłumaczeniu oznacza kształt, natomiast w odniesieniu do turystyki może określać „postać czy wygląd”. W pracach dotyczących turystyki pojęcie forma funkcjonuje równolegle $\mathrm{z}$ określeniem rodzaj turystyki (GAWORECKI 2010). Autorzy książki Turystyka" (KUREK, red. 2007) pojęcie „forma turystyki” rezerwują dla określenia różnych kategorii ruchu turystycznego, bliżej rozwijając formy turystyki: poznawczej, wypoczynkowej, kwalifikowanej, zdrowotnej, religijnej i biznesowej. Oddzielnie omawiają natomiast turystykę w wybranych typach przestrzeni geograficznej. Przedstawiona $\mathrm{w}$ tej pracy kwalifikacja form i rodzajów turystyki jest logiczna i dobrze porządkuje różnorodność określeń „turystyka" ze względu na celowość podejmowania wyjazdu turystycznego oraz miejsce jego realizacji.

Autorzy cytowanej tu pracy mają świadomość, że przedstawiona przez nich klasyfikacja ruchu turystycznego nie jest jedyną możliwą i wymieniają także inne kryteria dające podstawę do kolejnych podziałów zjawiska turystyki, np. według grup społecznych, długości pobytu, zasięgu przestrzennego wyjazdów (przyjazdów), liczby uczestników, organizatorów wyjazdu czy środków transportu. Zapewne lista ta nie jest zamknięta i może być uzupełniana, czego przykłady można spotkać np. w pracy W.W. GAWORECKIEGO (2010), który wymienia również jako kryteria podziału m.in. rodzaj finansowania wyjazdu, porę roku, rodzaj zakwaterowania, aspekt socjalny, zachowanie się $\mathrm{w}$ podróży i inne. Ten krótki przegląd istniejących $\mathrm{w}$ Polsce opracowań zdaje się wskazywać, że określenie „forma turystyki” zostało uznane, zwłaszcza wśród badaczy tego zjawiska za słowo „wytrych”, które można wykorzystać do określania różnych podziałów i klasyfikacji turystyki.

Aby zapobiec dalszemu chaosowi terminologicznemu i uporządkować znaczeniowo różne określenia, proponuję, pojęcie „forma turystyki” zarezerwować dla rodzaju (kategorii) ruchu turystycznego o określonym celu (motywie), od którego wywodzić się będzie jej nazwa. Uszczegółowieniem jej może być sposób aktywności turystycznej podczas konkretnego wyjazdu.

Przyjmując tradycyjne cele (motywy) wyjazdów turystycznych przykładowo można wymienić główne formy turystyki:

- turystyka wypoczynkowa (rozrywkowa, aktywna itp.);

- turystyka zdrowotna (np. lecznicza, kulturalna);

- turystyka religijna (m.in. poznawcza, kontemplacyjna); 
- turystyka poznawcza = krajoznawcza (miejska, górska itd.).

Wszystkie pozostałe kryteria, głównie związane z cechami demograficznymi, społecznymi turysty, jak również z organizacją wyjazdu, długością, warunkami pobytu i inne należy wykorzystać jako czynniki (wewnętrzne lub zewnętrzne) wpływające w określony sposób na realizację każdej formy ruchu turystycznego.

Konkludując, zdaniem autora, pojęcie „forma turystyki” określa rodzaj podróży w czasie wolnym zdefiniowany celem, jaki wyznacza człowiek podejmując tę aktywność. W tak rozumianej formie (rodzaju) turystyki człowiek jest zawsze podmiotem tego zjawiska. To on decyduje o celu, czasie i zakresie przestrzennym realizacji aktywności turystycznej.

Pragnę zwrócić uwagę, że przyjęcie tych założeń, a zwłaszcza podmiotowości turystyki, eliminuje lub znacznie ogranicza możliwość uznania za turystyczne wyjazdy zlecane czy zalecane przez pracodawcę (?), np. biznesowe, konferencyjne czy inne zawodowe.

Takie zdefiniowanie formy turystyki wymaga dalszego sprecyzowania i wszechstronnych studiów empirycznych dotyczących zarówno najstarszych, ale wciąż aktualnych motywów wyjazdów turystycznych (poznanie, wypoczynek, zdrowie, religia), jak i wiele nowych powstających w ostatnich latach (rozrywka, integracja zawodowa, event tourism, turystyka kulturowa, turystyka socjalna i inne).

Należy także rozważyć, czy budować jedną klasyfikację form turystyki uwzględniającą zarówno motywy (cele) wyjazdów, jak i sposób ich realizacji, czy też tworzyć oddzielną klasyfikację odnośnie do celów wyjazdów i oddzielną dla form aktywności turystycznej podczas tych wyjazdów.

\section{Geograficzna klasyfikacja turystyki}

Związki i uzależnienia zjawiska turystyki od środowiska geograficznego są na tyle oczywiste, że nie wymagają szczegółowego omówienia. Wystarczy tylko przypomnieć, że zjawisko turystyki realizowane jest (odbywa się) w zróżnicowanej przestrzeni geograficznej, która jest zarazem jednym z głównych walorów, ale również motywów ruchu turystycznego będącego synonimem turystyki. Ten związek i zależność rozwoju turystyki od środowiska geograficznego coraz rzadziej dostrzegany jest w literaturze przed- 
miotu i to zwykle w odniesieniu do walorów przyrodniczych. Zapominanie $\mathrm{w}$ badaniach nad turystyką o środowisku geograficznym jest zupełnie nieuzasadnione, wszak jego przestrzenne zróżnicowanie było przyczyną „narodzin” ruchu turystycznego i do dzisiaj pozostaje najważniejszym czynnikiem rozwoju turystyki.

Przyczyny zasygnalizowanego tu stanu tkwią głównie wśród samych geografów, którzy bardziej zajmują się obecnie efektami działalności turystycznej (co jest niewątpliwie ważnym problemem badawczym), niż jej przestrzennym zróżnicowaniem w środowisku geograficznym, co jest niezbywalną powinnością geografów.

Wychodząc z założenia, że podstawą zróżnicowania powierzchni Ziemi na komponenty przyrodnicze modyfikowane w części przez działalność człowieka, które geografowie fizyczni nazywają geokompleksami lub krajobrazem geograficznym, oraz że użytkowanie środowiska geograficznego przez turystykę owocuje powstaniem funkcjonalnych przestrzeni turystycznych, podjęto próbę stworzenia ogólnych ram geograficznej klasyfikacji turystki. Geograficzność tej klasyfikacji polega na identyfikacji formy (rodzaju) turystyki odczytywanej za pośrednictwem typu przestrzeni turystycznej $\mathrm{z}$ typem krajobrazu geograficznego, w którym ta forma jest realizowana lub w którym dominuje.

Celem tak pomyślanej klasyfikacji jest próba geograficznego skodyfikowania form (rodzajów) turystyki istniejących obecnie, ale również i tych, które mogą powstać w przyszłości i skorelowania ich z typem krajobrazu geograficznego. Warunkiem tej klasyfikacji jest uznanie, że formą turystyki nazywać będziemy taką aktywność turystyczną człowieka i rodzaj turystyki, która generuje przestrzeń turystyczną.

Pojęcie "krajobraz geograficzny" w tej pracy przyjęto za A. RICHLINGIEM i K. OSTASZEWSKA (2006), którzy za krajobraz geograficzny uważają: „Zewnętrzny wygląd Ziemi z określonego miejsca". W odniesieniu do obszaru Polski typy krajobrazów geograficznych są mocno zbliżone (w odpowiedniej skali) do regionów fizycznogeograficzych naszego kraju. W proponowanej klasyfikacji geograficznych form turystyki (tab. 1) wyróżniono 13 typów krajobrazów geograficznych.

Określenia „przestrzeń turystyczna” i „typy przestrzeni” zaczerpnięto z prac S. LISZEWSKIEGO (1995) i B. WŁODARCZYKA (2009). Przyjęto założenie, że każda forma (rodzaj) turystyki, której przejawem jest ruch turystyczny, 
zawłaszcza w sensie funkcjonalnym określoną część przestrzeni geograficznej - krajobrazu geograficznego.

Tabela 1. Klasyfikacja geograficzna form (rodzajów turystyki) na obszarze Polski

\begin{tabular}{|l|c|c|c|c|c|}
\hline \multirow{2}{*}{\multicolumn{1}{c|}{$\begin{array}{c}\text { Typy krajobrazu } \\
\text { geograficznego }\end{array}$}} & \multicolumn{5}{c|}{ Typy przestrzeni turystycznej } \\
\cline { 2 - 6 } & eksploracji & penetracji & asymilacji & kolonizacji & urbanizacji \\
\hline Morski & $\mathrm{X}$ & & $\mathrm{X}$ & & \\
\hline Nadmorski (pobrzeży) & & $\mathrm{X}$ & $\mathrm{X}$ & $\mathrm{X}$ & $\mathrm{X}$ \\
\hline Pojezierny & $\mathrm{X}$ & $\mathrm{X}$ & $\mathrm{X}$ & $\mathrm{X}$ & \\
\hline Nizinny & & $\mathrm{X}$ & & & \\
\hline Pradolin i dolin rzecznych & $\mathrm{X}$ & $\mathrm{X}$ & & & \\
\hline Wyżynny & & $\mathrm{X}$ & & & \\
\hline Górski & $\mathrm{X}$ & $\mathrm{X}$ & $\mathrm{X}$ & & \\
\hline Rolniczy & & & $\mathrm{X}$ & $\mathrm{X}$ & \\
\hline Leśny i bagienny & $\mathrm{X}$ & $\mathrm{X}$ & & & \\
\hline $\begin{array}{l}\text { Naturalnych obszarów } \\
\text { chronionych }\end{array}$ & $\mathrm{X}$ & $\mathrm{X}$ & & & \\
\hline Miejski & & $\mathrm{X}$ & $\mathrm{X}$ & $\mathrm{X}$ & \\
\hline Podmiejski & $\mathrm{X}$ & $\mathrm{X}$ & & $\mathrm{X}$ & $\mathrm{X}$ \\
\hline Przemysłowy & & & & \\
\hline
\end{tabular}

Objaśnienia: Krzyżykami zaznaczono potencjalne formy (rodzaje) turystyki, które rozwijając się w określonym typie krajobrazu tworzą odpowiedni typ przestrzeni turystycznej. Przykładowo, w krajobrazie morskim dominuje przestrzeń eksploracji (odkrywanie nowych akwenów) i asymilacji (pobyt grupy osób na statku, jachcie itp.). W krajobrazie miejskim dominują przestrzenie: penetracji turystycznej (poznawanie miasta), asymilacji turystycznej (np. udział w masowych imprezach kulturalnych) i kolonizacji turystycznej (trwała infrastruktura turystyczna: hotele, restauracje, muzea itp.).

Źródło: opracowanie własne.

Przedstawiona tabela klasyfikacyjna (tab. 1) wymaga identyfikacji już istniejących czy powstających form turystyki i przed umieszczeniem ich w odpowiednim miejscu w tabeli opisania dwoma parametrami: typem krajobrazu geograficznego, w którym jest realizowana, i typem wytworzonej w czasie użytkowania przestrzeni turystycznej.

Weryfikacja poprawności klasyfikacji wymaga szczegółowych studiów terenowych, identyfikujących rodzaje uprawianej turystyki w wybranym typie krajobrazu geograficznego, albo stworzenia katalogu występujących $\mathrm{w}$ literaturze form turystyki, stwierdzenia, czy ich realizacja tworzy funkcjonalną przestrzeń turystyczną (i jaką), a następnie określenie typu krajobrazu geograficznego, w którym jest ona realizowana. 
Tabelę 1 należy traktować jako podstawę do dyskusji, a obie korelowane w niej formy przestrzeni (geograficzna i turystyczna) mogą ulegać i rozszerzeniu, i modyfikacji. Tabela jest określonym schematem i wymaga wypełnienia konkretnymi formami (rodzajami) turystyki. Może ona posłużyć do klasyfikacji turystyki zarówno w całym kraju, jak i w jakimś jego regionie.

\section{Podsumowanie i wnioski}

Zasygnalizowane $\mathrm{w}$ tym opracowaniu zagadnienia skłaniają do przedstawienia wniosków o charakterze ogólnym.

Pierwszy z nich ma charakter postulatowy. Wydaje się, że rozwój zjawiska turystyki zmusza zajmujących się nim badaczy do poważnej dyskusji terminologicznej. Może warto po odpowiednim przygotowaniu zorganizować sympozjum interdyscyplinarne (międzynarodowe), z udziałem GUS oraz innych urzędów i organizacji, poświęcone nowemu zdefiniowaniu zagadnień terminologicznych $\mathrm{w}$ turystyce. Warto $\mathrm{w}$ tym zakresie odwołać się do dorobku sympozjum, które odbyło się w 1974 r. w Krakowie i Zakopanem (WARSZYŃSKA, JACKOWSKI 1976).

Przygotowując się do generalnej dyskusji należy starannie wykonać katalog nazw form turystyki używanych w literaturze turystycznej i w działalności gospodarczej w Polsce i na świecie. Katalog taki mógłby być m.in. efektem dyskusji podczas dorocznej konferencji łódzkiej pt. „Warsztaty z geografii turyzmu".

Ze względu na różnorodność rozumienia pojęć, ale także z uwagi na potrzeby praktyczne warto rozważyć możliwość przeprowadzenia odpowiednich studiów i wydania drukiem przynajmniej dwóch brakujących w literaturze polskiej opracowań. Pierwsze powinno dotyczyć kompleksowego omówienia walorów antropogenicznych w turystyce (analogia do istniejących prac dotyczących walorów przyrodniczych, m.in. K. KOŻUCHOWSKIEGO z 2005 czy Z. MŁYNARCZYKA i A. ZAJADACZ z 2008 r.), drugie przestrzennego zróżnicowania turystyki w środowisku geograficznym, np. Polski czy Europy Środkowej (regionalizacje turystyczne). W realizacji tej drugiej pracy może być pomocna zaprezentowana w tym opracowaniu „Klasyfikacja geograficzna form (rodzajów) turystyki na obszarze Polski”. 


\section{BIBLIOGRAFIA}

GAWORECKI W.W., 2010, Turystyka, PWE, Warszawa.

KotLiCKA J., 2010, 31. Międzynarodowa Konferencja Promieniowania Kosmicznego w Łodzi jako przykład turystyki kongresowej (Studium przypadku), „Turyzm” 10(1), s. 51-55.

KOŻUCHOWSKI K., 2005, Walory przyrodnicze w turystyce i rekreacji, Wyd. „Kurpisz”, Poznań.

KUREK W. (red.), 2007, Turystyka, Wyd. Naukowe PWN, Warszawa.

LISZEWSKI S., 1995, Przestrzeń turystyczna, „Turyzm” 5(2), s. 8-103.

LISZEWSKI S., 2005, Koncepcja zintegrowanych badań nad turystyka, [w:] B. Domański, S. Skiba (red.), Geografia i sacrum, t. 2, Instytut Geografii i Gospodarki Przestrzennej UJ, Kraków, s. $105-113$.

MŁynarCZYK Z., ZajAdACZ A. (red.), 2008, Przyrodnicze zasoby turystyczne i metody ich oceny, „Turystyka i Rekreacja - Studia i Prace”, 1, Wyd. Naukowe UAM, Poznań.

Richling A., OstaszeWSKA K. (red.), 2006, Geografia fizyczna Polski, Wyd. Naukowe PWN, Warszawa.

SZYMAŃCZYK M., 2010, Wypoczynek weekendowy i urlopowy Polaków przebywajacych w Anglii oraz Brytyjczyków, maszynopis pracy magisterskiej w Instytucie Geografii Miast i Turyzmu Uniwersytetu Łódzkiego.

SZYMCZAK M., (red.) 1978, Stownik języka polskiego, t. 1, PWN, Warszawa.

WARSZYŃSKA J., JACKOWSKI A. (red.), 1976, Zagadnienia terminologii w geografii turyzmu. Materiaty międzynarodowego sympozjum, Kraków-Zakopane 7 listopada 1974 r., Zeszyty Naukowe Uniwersytetu Jagiellońskiego, 429, Prace Geograficzne, 42.

WŁodarczYK B., 2009, Przestrzeń turystyczna. Istota. Koncepcje. Determinanty rozwoju, Wyd. Uniwersytetu Łódzkiego, Łódź. 